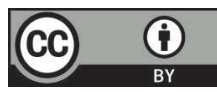

\title{
The variations in the trends of novel coronavirus disease cases reported in Sri Lanka and the public health response
}

Dharmaratne $\mathrm{SD}^{1}$, Gunasena $\mathbf{P}^{2}$, Gunathunga $\mathbf{M W}^{3}$, Kothalawala $\mathbf{M}^{4}$, Sudaraka MDS $^{5}$, Abeyagunawardena IA ${ }^{5^{*}}$

${ }^{1}$ Department of Community Medicine, Faculty of Medicine, University of Peradeniya, Sri Lanka; ${ }^{2}$ Lanka Hospital, Sri Lanka; ${ }^{3}$ Department of Community Medicine, Faculty of Medicine, University of Colombo, Sri Lanka; ${ }^{4}$ Faculty of Medicine, University of Peradeniya, Sri Lanka

"Correspondence: ishanya1993@gmail.com

(iDhttps://orcid.org/0000-0003-0395-7863

DOI: https://doi.org/10.4038/jccpsl.v26i5.8319

Received on 7 May 2020

Accepted on 28 June 2020

\section{Summary}

Sri Lanka reported its first case of coronavirus disease-19 (COVID-19) on 27 January 2020, a Chinese female visiting the country (1). Following this, no new case was reported until 11 March 2020, when the first local COVID-19 patient was discovered (2). This narrative report aims to describe the trends of the caseload of COVID-19 across Sri Lanka in relation to the control measures implemented.

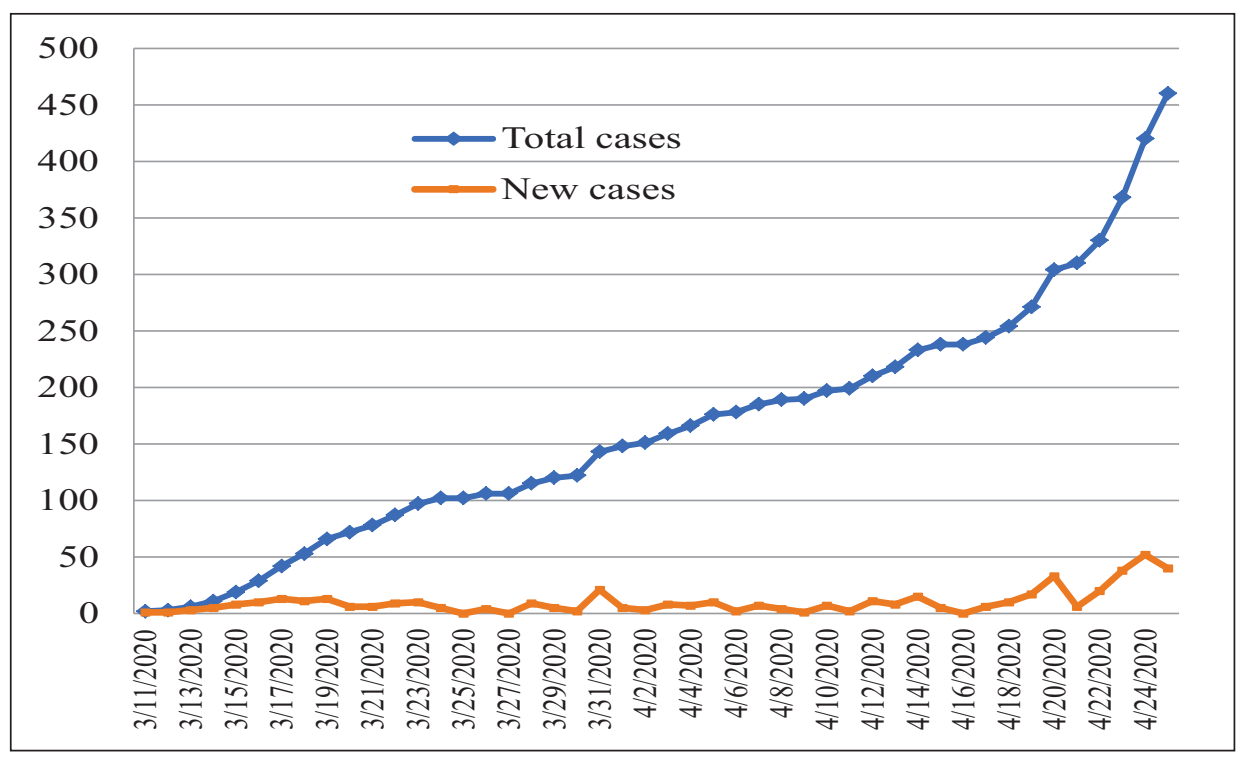

Figure 1: Total and new COVID-19 patients reported from 11 March to 26 April 2020 


\section{Public health response and its impact}

\section{Method of secondary data analysis}

The daily number of cases reported up to 26 April 2020 was obtained from daily situation reports of the Epidemiology Unit, Sri Lanka. Information regarding the control measures was obtained from the circulars issued by the Ministry of Health, reports available online from the Ministry of Defence and press releases. The data were used to produce models with best fitting trend lines for the caseload reported in Sri Lanka using $\mathrm{R}$ software version 3.6.3. The control measures responsible for the variation in trends were postulated. $\mathrm{R}^{2}$ was used to depict how close the data fit the regression line. Higher the $\mathrm{R}^{2}$ (closer to 1) the better the model fits the data analysed (3).

\section{Results}

Figure 1 depicts the spread of the disease up to 26 April 2020.

It was observed that the total number of patients reported (including local cases and returnees from abroad) up to 16 March 2020 fit into an exponential regression model $\left(\mathrm{R}^{2}=0.994\right)$ (Figure 2$)$. This time period was determined, after assessing the performance of multiple linear and exponential regression models created for different time periods; and not based on the timing of control measures taken.

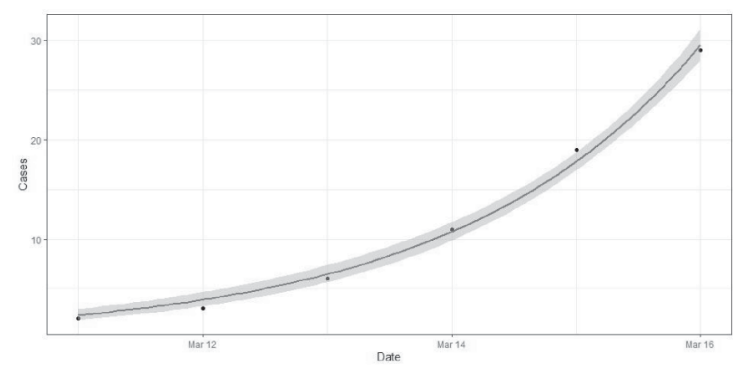

Figure 2: Total cases in Sri Lanka from 11 March to 16 March 2020 showing an exponential rise $\left(R^{2}=0.994\right)$

Subsequently, the trend shifted to a linear pattern from 16 March to 23 March 2020 (Figure 3), the slope was calculated to be 9.31 cases per day ( $95 \%$ confidence interval $(\mathrm{CI})=8.177,10.442 ; \mathrm{p}<0.001$; standard error $\left.(\mathrm{SE})=0.4628 ; \mathrm{R}^{2}=0.985\right)$. Selection of this time period was not based on the timing of preventive measures. It was selected because when a series of linear regressions was performed, a significant change in the trend slope was observed from 24 March onwards.

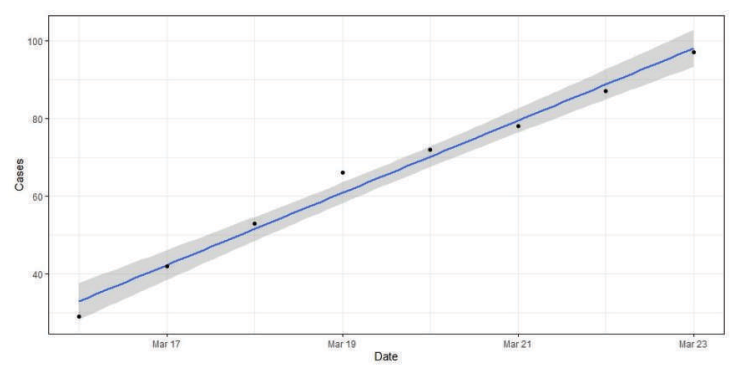

Figure 3: Total number of cases reported each day from 16 March to23 March $2020\left(R^{2}=0.985\right)$

Data from 24 March to 19 April 2020 (Figure 4) also followed a linear trend $\left(R^{2}=0.989\right)$, however the slope of this curve had reduced to 6.429 cases/day (95\% CI=6.157, 6.701; $\mathrm{p}<0.001 ; \mathrm{SE}=0.132)$. This is depicted in Figure 4. Reduction of this slope was statistically significant. From 19 April 2020 onwards, the detection of two clusters of patients resulted in a change in the pattern of spread.

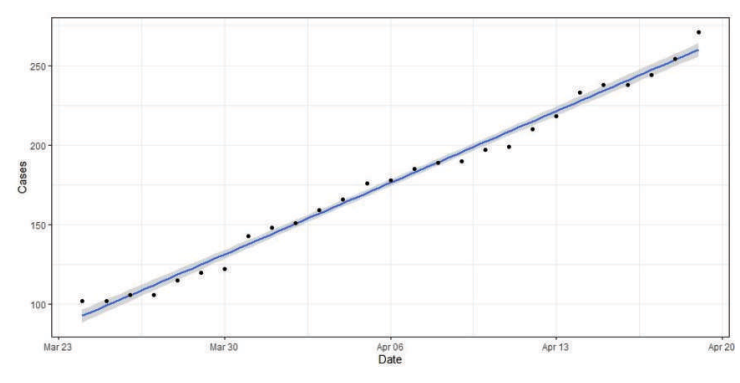

Figure 4: Total number of cases reported each day from 24 March to 19 April $2020\left(R^{2}=0.989\right)$

\section{Discussion}

The first few days following the diagnosis of the first local patient (from 11 March to 16 March 2020) showed an exponential rise in the total daily cases reported. This is not unexpected, with the major preventive action such as suspension of flights and implementation of nationwide curfew (Figure 5) being implemented only after 19 March 2020. 
However, during this period, schools and universities were closed and large gatherings were prohibited from 16 March onwards (4). Regarding air travel, provision of visa on arrival was suspended, travel bans on multiple countries and measures for screening such as infrared cameras to detect patients with fever and self-declaration forms were implemented. Sri Lankan passengers from countries in Europe were quarantined in centres through exhaustive efforts of the Army (4-5). On 16 March, public holidays were declared. and the public was encouraged to practise social distancing and work from home (6-7) (Figure 5). With all these measures in place, the trend line shifted from an exponential pattern to a linear pattern with a slope of 9.31 cases per day, as illustrated in Figure 3 .

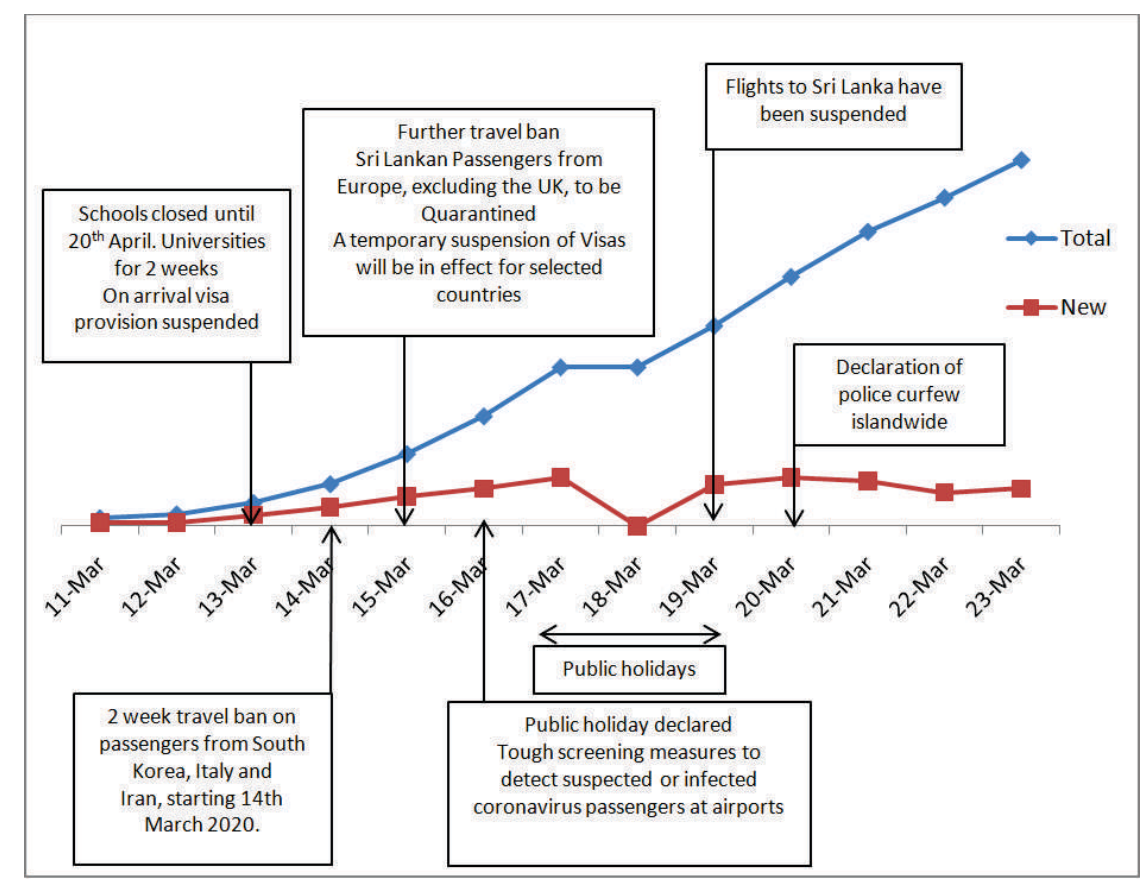

Figure 5: Interventions implemented to limit the spread of the disease

There are multiple reasons which could explain the significant reduction of the slope, which took place after 23 March to 6.429 cases per day. A coordinated plan of action where the police, military, healthcare workers and intelligence services work synchronously, each carrying out a specific role was formulated. Detection of cases, isolation, tracing and quarantining of contacts were the cornerstones of the effort mounted to curb the spread of COVID-19. The contacts were identified by the public health sector with the assistance of State Intelligence and Epidemiology Unit, while the military ensured the containment of the disease together with the Sri Lanka Police to reduce the spread by imposing limitations on the mobility of the public. The public health sector also took on the role of health promotion and maintenance of the records for formulating future strategies. Readiness of the curative sector was ensured by identifying designated hospitals, recommissioning of existing hospitals and improvising selected facilities at hospitals to admit and treat the patients with COVID-19(8).

As depicted in Figure 5, the Sri Lanka Police implemented a nationwide curfew from 20 March (9-10), which was subsequently extended in high risk areas (11). All those returning from abroad were asked to register with the police and practice selfisolation at home for a period of 14 days (9). The contacts of those infected were meticulously traced and asked to self- quarantine (12). The exhaustive contact tracing identified family members, close associates, distant associates as well as individuals inadvertently exposed due to movement of the 
infected individual during his infectious period. This was achieved by ground surveillance and questioning of the infected individuals, by records such as hotel/travel reservations and by utilization of the telecommunication networks. According to the degree of exposure, these individuals were quarantined in quarantine centres or at home (8). All those practising self-quarantine were supervised by the public health inspector (PHI) (13). A certification of completion of the quarantine period was issued and legal action taken against those who did not comply with these measures (14-15). However, two clusters of cases, as illustrated in Figure 6 led to a dramatic increase in the number reported after 20 April 2020 (16-18).

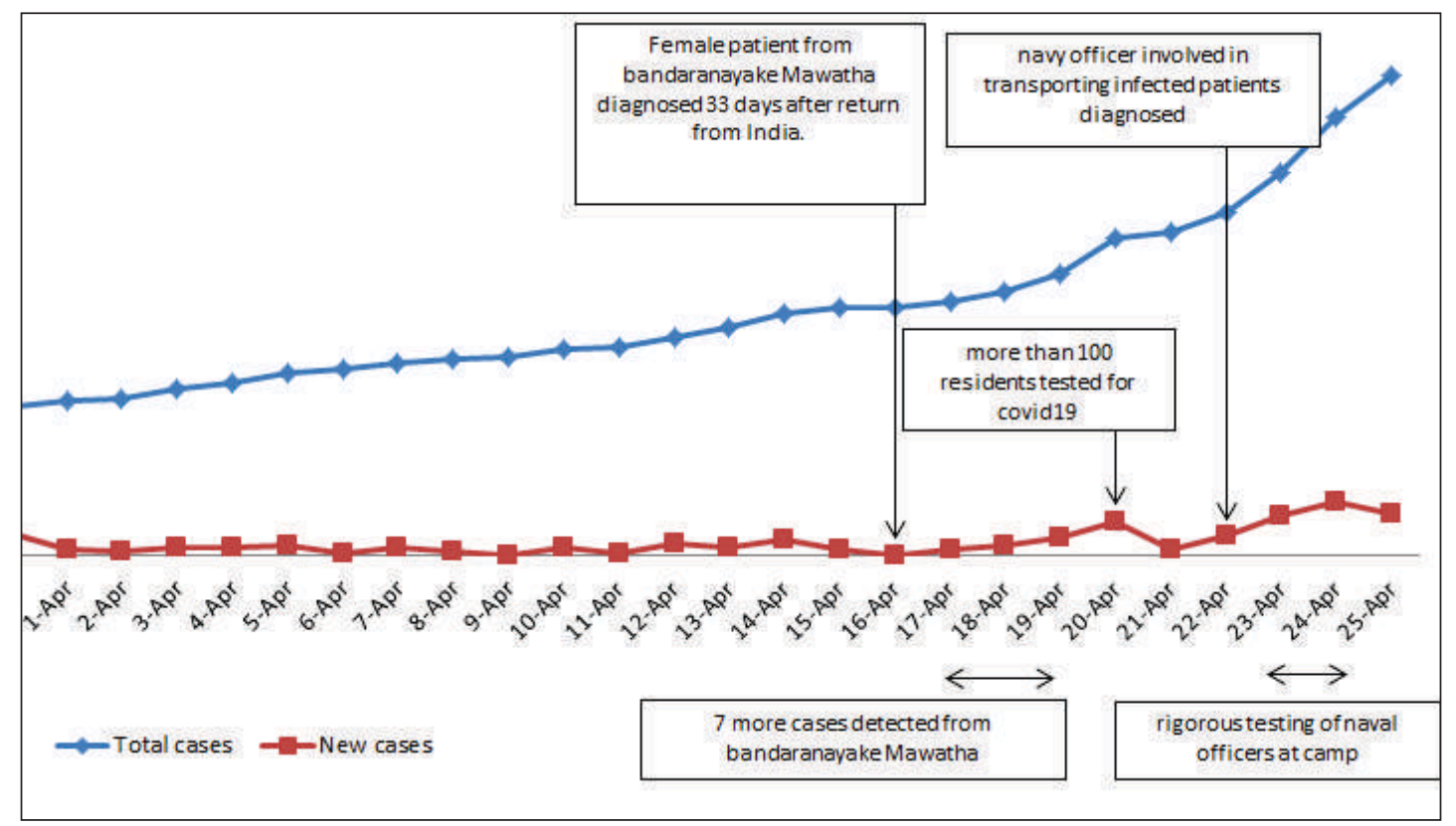

Figure 6: The timing of two incidents and the aftermath which led to the rise of reported cases

It is evident that prior to the two clusters identified, the spread of COVID-19 in Sri Lanka had been relatively well-controlled. Figure 7 depicts the daily total cases reported in countries worldwide, since the day of their first reported case in log scale (19), in which the USA, Italy, Spain and Sri Lanka are highlighted.

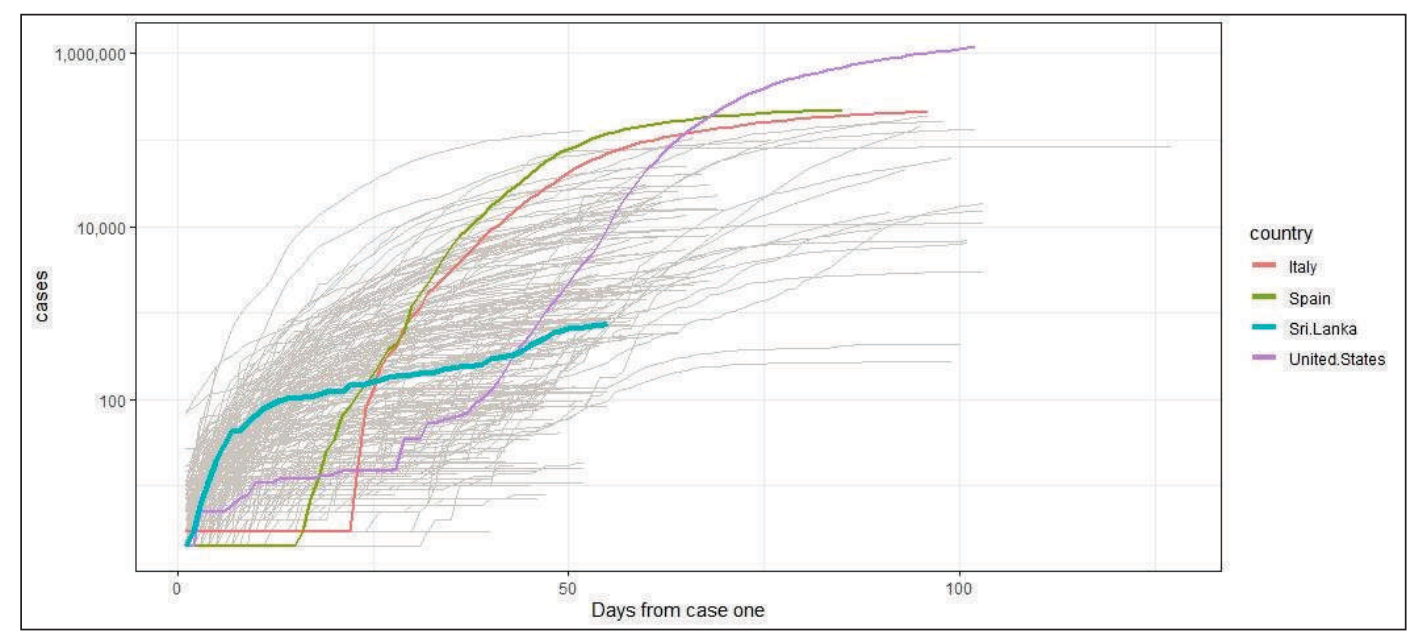

Figure 7: Number of confirmed cases of COVID- 19 reported from the first day of the first case for countries worldwide using a log scale 
Interestingly, the USA being among the highest hit countries, allocates $17.7 \%$ of its gross domestic product (GDP) towards healthcare, the highest worldwide. However, only $2.56 \%$ was allocated to public health according to figures published in 2018 (20). Sri Lanka allocated only $3.4 \%$ of its GDP to healthcare (2015), however it has a well-developed public health system, with many public health success stories to its name (21-22).

A limitation of this paper is that returnees from abroad and local cases have not been analysed separately. However, since there were local patients with exposure histories to returnees from abroad (23), these two groups are not mutually exclusive, hence the analysis was done for the total cases reported as a whole. Furthermore, preventive measures usually take a certain time period to produce a response, which was not considered in the analysis. However, as the measures in question were aggressive actions (isolating patients in designated hospitals, quarantining contacts, halting overseas travel, etc.), which prevented the virus gaining foothold within the community, we believe they yielded instantaneous results as well as contributing to long-term control.

\section{Conclusions}

Despite being a developing country with a relatively less financed health sector, the collaborations made between the military, intelligence, police and the well-developed public health sector in the country helped control the spread of the disease in Sri Lanka. We believe that this same method can be used with local adaptation by other countries who have not utilized such an approach to combat future pandemics.

\section{Author Declaration}

Acknowledgements: We would like to acknowledge the Tri-forces, Police, Ministry of Health and the Epidemiology unit along with the Government of Sri Lanka, for compiling the data utilized in this paper and making it accessible to all.

Author contributions: SDD conceived, designed and implemented this report. MDSS extracted, processed and analysed the data from the Epidemiology Unit, Ministry of Health, Sri Lanka. IAA wrote the first draft of the paper and finalized the manuscript based on comments from other authors. All authors provided intellectual input into all aspects of this report and contributed to the final manuscript.

\section{References}

1. Gunaratna G. First patient with coronavirus reported in Sri Lanka. ColomboPage, Sri Lanka Internet Newspaper, 27 January 2020. Available from: http://www.colombopage.com/archive_20A/Jan 27_1580144354CH.php.

2. Gunaratna G. First Sri Lankan coronavirus patient in the country identified. ColomboPage, Sri Lanka Internet Newspaper, 11 March 2020. Available from: http://www.colombo page.com/archive_20A/ Mar11_1583903965CH.php

3. Data Science Central. How to interpret R-squared and goodness-of-fit in regression analysis. Post by Emmanuelle Rieuf, 11 February 2017. Available from: https:/www. datasciencecentral.com/profiles/ blogs/regression-analysis-how-do-i-interpret-rsquared-and-assess-the. Accessed 20 April 2020.

4. Updates on COVID-19. Sri Lankan situation. Available from: https://srilanka.travel/covid19/. Accessed 20 April 2020.

5. Ministry of Defence Sri Lanka. AASL Chief rebuffs rumors on plans to shut down airports due to COVID19. News, 16 March 2020. Available from: http://www.defence.lk/Article/view_article/914.

6. Gunaratna G. Coronavirus update: Sri Lanka declares Monday a public holiday as COVID-19 spreads. ColomboPage, Sri Lanka Internet Newspaper, 14 March 2020. Available from: http://www.colombopage.com/archive_20A/Mar14 _1584205340CH.php.

7. Riyaz ul Khaliq. Sri Lanka announces 3-day holiday to fight coronavirus. Health_Asia Pacific, 17 March 2020. Available from: https:// www.aa.com.tr/en /asia-pacific/sri-lanka-announces-3-day-holiday-tofight-corona virus/1768675.

8. Gokhale NA. Combatting COVID-19: the Sri Lankan approach. StratNews Global, 24 April 2020. Available from: https://stratnewsglobal .com/ combatting-covid-19-the-sri-lankan-approach/. 
9. Gov.UK. Coronavirus (COVID-19) foreign travel advice, Sri Lanka. Available from: https://www. gov.uk/foreign-travel-advice/sri-lanka/coronavirus. Accessed 20 April 2020.

10. Department of Government Information. Island wide curfew notice. Press Release 2020.03.20. Available from: https://www.dgi.gov.lk/ news/ press-releasessri-lanka/1956-press-release-2020-03-22.

11. Thasleem A. Sri Lanka extends nationwide curfew to fight coronavirus pandemic. Aljazeera News, 23 March 2020. Available from: https://www.aljazeera. com/news/2020/03/coronavirus-pandemic-sri-lankaextends-curfew-worst-hit-areas-20032311 36013 72.html.

12. News $1^{\text {st }}$. Intelligence units to trace contacts of COVID - 19 patients. Available from: https:// www.newsfirst.lk/2020/04/18/intelligence-units-totrace-contacts-of-covid-19-patients/. Accessed 20 April 2020.

13. Epidemiology Unit. Guideline for the Home Quarantine/ Quarantine in Non-health Care Settings. Colombo: Ministry of Health. Available from: http://www.epid.gov.lk/ web/images/pdf /Circulars/ Corona_virus/guidelines-ofhome-quarantine.pdf. Accessed 25 April 2020.

14. Gunaratna G. Coronavirus update: more quarantined returnees leave centers heading home. Colombo Page, Sri Lanka Internet Newspaper, 30 March 2020. Available from: http://www.colombo page.com/ archive_20A/Mar30_1585591969CH.php.

15. Epidemiology Unit. Police act on quarantine of suspected corona patients / contacts. Colombo: Ministry of Health. Available from: http://www.epid. gov.lk/web/images/pdf/Circulars/Corona_virus/med ia\%20on\%202020.03.14\%20at\%202330\%20police \%20act.pdf. Accessed 25 April 2020.
16. News $1^{\text {st }}$. COVID-19 tests to be carried out on more than 100 people in Colombo. Available from: https://www.newsfirst.1k/2020/ 04/19/covid-19tests-to-be-carried-out-on-more-than-100-peoplein-colombo/. Accessed 25 April 2020.

17. News $1^{\text {st }} .30$ sailors from Welisara Navy Camp tested positive for COVID-19. Available from: https://www.newsfirst.lk/2020/04/23/30-sailorsfrom-welisara-navy-camp-tested-positive-forcovid-19/. Accessed 30 April 2020.

18. EconomyNext. Welisara Navy COVID 19 "cluster" has yielded 206 patients, as total reaches 596. 28 April 2020. Available from: .

19. Our World in Data. Coronavirus Pandemic (COVID19). Available from: https:// ourworldindata.org/ coronavirus. Accessed 6 May 2020.

20.Centers for Medicare and Medicaid Services. Historical. Available from: https://www. cms.gov/Research-Statistics-Data-and-Systems/ Statistics-Trends-and-Reports/ NationalHealth ExpendData/NationalHealthAccountsHistorical. Accessed 30 April 2020.

21. Institute for Health Policy, Sri Lanka. Sri Lanka Health Accounts: National Health Expenditure 1990-2016. Available from: http://www.ihp.lk/ publications/docs/HES1805.pdf. Accessed 30 April 2020.

22.World Health Organization. Public Health Success in Sri Lanka. Available from: http://origin.searo. who.int/srilanka/documents/policybriefsfinal.pdf. Accessed 25 April 2020.

23.Epidemiology Unit. Exposure History of Covid-19 diagnosed cases of Sri Lanka as on 27/03/2020. Colombo. Ministry of Health. Available from: https://www.epid.gov.lk/ web/images/pdf/Circulars/ Corona_virus/connections\%20new\%20v02.pdf. Accessed 30 April 2020. 